\title{
Phytophthora abietivora, A New Species Isolated from Diseased Christmas Trees in Connecticut, U.S.A.
}

\author{
De-Wei Li ${ }^{1,2}$, Neil P. Schultes ${ }^{3}$, James A. LaMondia ${ }^{1}$, and Richard S. Cowles ${ }^{1, \dagger}$ \\ ${ }^{1}$ The Connecticut Agricultural Experiment Station, Valley Laboratory, Windsor, CT 06095, U.S.A. \\ ${ }^{2}$ Co-Innovation Center for Sustainable Forestry in Southern China, Nanjing Forestry University, Nanjing, Jiangsu 210037, China \\ ${ }^{3}$ The Connecticut Agricultural Experiment Station, Department of Plant Pathology and Ecology, New Haven, CT 06511, U.S.A.
}

\begin{abstract}
A number of fir species (Abies) are produced as Christmas trees around the world. In particular, Fraser fir (Abies fraseri (Pursh) Poir.) is popular as it yields high-quality Christmas trees in temperate North America and Europe. A Phytophthora sp. causing root rot on Fraser fir was isolated from a Christmas tree farm in Connecticut, U.S.A., and found to be

analysis using multilocus DNA sequences from ITS, Cox1, $\beta-T u b$, Nadh1, and Hsp90 loci. Thus, it was described and illustrated as Phytophthora abietivora. An informative Koch's postulates test revealed that $P$. abietivora was the pathogen causing root rot of Fraser fir.
\end{abstract} new to science according to morphological and molecular phylogenetic
Keywords: multi loci, oomycetes, pathogenicity, phylogeny, zoospore
A number of firs (Abies spp.) are grown as Christmas trees. Fraser fir, Abies fraseri (Pursh) Poir., is native to the Appalachian Mountains of the Southeastern United States (Hunt 1993) and is one of the predominant species of Christmas trees (Talgø and Chastagner 2012), producing high-quality Christmas trees in Connecticut and other states in the U.S.A., Canada, and Europe. Phytophthora root rot is a serious disease of Abies spp., which leads to significant losses from Christmas tree farms and conifer nurseries (Chastagner and Benson 2000; Hinesley et al. 2000; McKeever and Chastagner 2016). Fraser fir is highly susceptible to root rot disease caused primarily by Phytophthora cinnamomi Rands and other Phytophthora species (Erwin and Ribeiro 1996; Hoover and Bates 2013; QuesadaOcampo et al. 2009) and the disease develops rapidly, with a majority of infected trees dying within 4 to 5 weeks (Chastagner and Benson 2000; Hinesley et al. 2000).

The genus Phytophthora has about 150 to 170 described species (Brasier 2009; Jung et al. 2016). Over 80 taxa are pathogenic causing devastating plant diseases worldwide and leading to severe economic losses each year (Judelson and Blanco 2005; Shamoun et al. 2018). Members of the genus Phytophthora are reported to infect more than 130 plant species and Tsao (1990) reports that Phytophthora spp. caused $>90 \%$ of all collar rots and $>66 \%$ of all fine root diseases of woody plants. Surveys by Jung et al. (2016) in Europe found 49 taxa of Phytophthora in nursery plants (most were healthy at the time of sampling), and 56 taxa of Phytophthora in forest and landscape plantings. Together, a total of 68 Phytophthora taxa were found. Among these 68 species, at least 47 taxa detected in nurseries and plantings were introduced species and seven were new species (Jung et al. 2016).

McKeever and Chastagner (2016) documented 13 species of Phytophthora causing root rot in Christmas trees of Abies spp. in the United States and 18 documented species on Abies spp. worldwide. Three additional species found to infect $A$. fraseri in North America

${ }^{\dagger}$ Corresponding author: R. S. Cowles; Richard.Cowles@ct.gov

Funding: This study is supported by a Specialty Crop Block Grant from the Connecticut Department of Agriculture, awarded to the Connecticut Christmas Tree Growers' Association.

The author(s) declare no conflict of interest.

Accepted for publication 6 July 2019

(C) 2019 The American Phytopathological Society are mentioned in the literature, for a total of 16 species: $P$. cactorum (Lebert \& Cohn) J. Schröt. in Connecticut, Michigan, Pennsylvania, and Wisconsin; P. cambivora (Petri) Buisman in Michigan, Oregon, and Washington; $P$. capsici Leonian in Michigan; $P$. cinnamomi Rands in North Carolina and West Virginia; P. citricola Sawada in Michigan and North Carolina; P. citrophthora (R.E. Sm. \& E.H. Sm.) Leonian in North Carolina; P. cryptogea Pethybr. \& Laff. in North Carolina and Pennsylvania; $P$. drechsleri Tucker in North Carolina and Pennsylvania; P. europaea E.M. Hansen \& T. Jung in Wisconsin; $P$. taxon 'kelmania' in Connecticut, New York, and North Carolina (this species has not yet been formally described [Phytophthora Database 2018]); P. megasperma Drechsler in Michigan; $P$. nicotianae Breda de Haan in Michigan; $P$. pini (belonging to a species complex of $P$. citricola) in Michigan, North Carolina, and New York; P. plurivora T. Jung \& T.I. Burgess (holotype MURU 433) in Connecticut, Michigan, North Carolina, and Wisconsin; P. pseudosyringae $\mathrm{T}$. Jung \& Delatour in Washington; and $P$. sansomeana E.M. Hansen \& Reeser in Michigan, New York, North Carolina, and Wisconsin (Adams 1988; Grand 1985; Hoover and Bates 2013; Huang et al. 2004; Kuhlman and Hendrix 1963; Martin et al. 2014; McKeever and Chastagner 2016; Pettersson et al. 2017; Quesada-Ocampo et al. 2009; Shew and Benson 1981; Williams and Haynes 1982).

Root rot leading to death of $A$. fraseri trees was found in a Christmas tree farm in Connecticut. Samples were collected from infected trees at the farm and one pathogen isolate belonging to Phytophthora $\mathrm{sp}$. was found to be new to science - here a novel fungal species is described and illustrated. Koch's postulates were tested to confirm the pathogenicity of the recovered Phytophthora spp.

\section{Materials and Methods}

Nine hundred 3- to 5-year-old Christmas trees of different species were planted into a field $\left(41^{\circ} 45.997^{\prime} \mathrm{N}, 71^{\circ} 55.182^{\prime} \mathrm{W}\right)$ in Brooklyn, CT, as bare-root transplants in 2010, among which 60 trees were Fraser fir. Within three years, all Fraser firs in this field had died. In a new experiment, 5-year-old bare-root Fraser fir seedlings were replanted in 2015 into this field. Ten presumably infected $A$. fraseri Christmas trees from this field were sampled on Oct. 10, 2017. Plants chosen for sampling were identified based upon subtle signs of poor color or chlorotic foliage on the lowest whorl of branches and were dug with intact major roots from the field. Diseased trees were transported to the laboratory, the roots washed with tap water but not surface sterilized, and root crown and stem lesions identified. Slivers of diseased tissue $(2 \times 2 \mathrm{~mm})$ from the interior of the stem were removed from the margin of lesions with a heat-sterilized scalpel and inserted 
into the flesh of apples ('Braeburn' fruits) through a slit in the skin of the fruit following the method of Tucker (1931). The apple fruits were incubated for a week at room temperature.

Lesions with brown discoloration within the apple flesh expanded outward from inoculated sites. Two isolates were obtained. The isolates were purified by cutting hyphal tips, which were cultured on PDA at $25^{\circ} \mathrm{C}$ for 7 days. A heat-sterilized scalpel was used to remove a $2 \times 2 \mathrm{~mm}$ piece, less than $1 \mathrm{~mm}$ in thickness, which was then placed on potato dextrose agar (PDA: $39 \mathrm{~g}$ dried powder, 1 liter water) and subsequently grown by inoculating three equidistant points in a triangle pattern on 10\% V8 agar (V8) (100 ml clarified V8 juice, $900 \mathrm{ml}$ water, $1 \mathrm{~g} \mathrm{CaCO}_{3}, 15 \mathrm{~g}$ agar; Ferguson and Jeffers 1999) at 15, 20, and $25^{\circ} \mathrm{C}$ for 7 to 30 days depending on rate of mycelial growth. To induce sporangia and zoospore formation, five V8 plates were flooded with nonsterile soil extract (Jeffers and Aldwinckle 1987) and another five were flooded and also embedded with Fraser fir root pieces $2 \mathrm{~cm}$ in length. A third method, flooding culture plates with soil-free root extracts, was also used to induce development of sporangia and zoospores. Live roots $(<5 \mathrm{~mm}$ diameter) from Fraser fir and red oak (Quercus rubra) were washed with deionized water. Ten grams of each, chopped into $1 \mathrm{~cm}$ segments, were soaked in $250 \mathrm{ml}$ of deionized water for $1 \mathrm{~h}$, then filtered through a $0.2 \mu \mathrm{m}$ filter and held at $4^{\circ} \mathrm{C}$ until used.

Pieces of colonies were mounted in $85 \%$ lactic acid on glass slides for microscopic observation. To monitor sporulation, aerial hyphae, and colony development, malt extract agar (MEA) (20 g malt, $20 \mathrm{~g}$ agar, and 1 liter distilled water) and V8 media were used. Colonies incubated at $25^{\circ} \mathrm{C}$ for a month on MEA plates were used for observing the growth, for preparing an extype, and for harvesting mycelium to conduct molecular studies. All observations and measurements of fungal structures were carried out under a compound microscope (Zeiss Imager.M2) with differential interference contrast (DIC). Photomicrographs were taken with an Axiocam 506 color camera (Carl Zeiss AG, Oberkochen, Germany). Measurements of the fungal structures were made under 40-100× objective lenses, from which means, standard deviations, and $95 \%$ confidence intervals of means were calculated using the Data Analysis Package of Excel 2016.

The holotype has been deposited in The UAMH Centre for Global Microfungal Biodiversity at University of Toronto (UAMH), Canada, and an ex-type in the NRRL Culture Collection, USDA, Peoria, IL, U.S.A.

DNA extraction, amplification, and sequencing. The isolate was grown on PDA at $25^{\circ} \mathrm{C}$, and on $\mathrm{V} 8$ at $15,20,25^{\circ} \mathrm{C}$ for up to one month. DNA was extracted from colonies grown in Petri plates according to the procedure in ZR Fungal/Bacterial DNA MicroPrep Kit (Zymo Research, Irvine, CA, U.S.A.). Portions of the $18 \mathrm{~S}$ ribosomal RNA including the internal transcribed spacers 1 and 2 and 5.8S ribosomal RNA gene (ITS), cytochrome c oxidase subunit 1 (Coxl), NADH dehydrogenase subunit 1 (Nadhl), heat shock protein 90 (Hsp90), and $\beta$-tubulin $(\beta$-Tub) loci were amplified from genomic DNA by polymerase chain reaction (PCR) using oligonucleotides $V 9 G$ or ITS5 with LRI (Van den Ende and De Hoog 1999; Vilgalys and Hester 1990; White et al. 1990), COXF4N and COXR4N (Kroon et al. 2004), NADHF1 and NADHR1 (Kroon et al. 2004), HCF90_F1 and HCF90_Rl (Blair et al. 2008), and TUBUF2 and TUBURI (Kroon et al. 2004), respectively. The parameters for the PCR amplification protocol were $94^{\circ} \mathrm{C} 3 \mathrm{~min} ; 94^{\circ} \mathrm{C} 30 \mathrm{~s}$; $45^{\circ} \mathrm{C} 30 \mathrm{~s} ; 72^{\circ} \mathrm{C} 2 \mathrm{~min}$, repeat $35 \times, 72^{\circ} \mathrm{C} 7 \mathrm{~min}$. Resulting amplified DNA products were purified using QIA quick PCR Purification columns (Qiagen, Valencia, CA, U.S.A.) and the DNA concentrations were determined on a NanoDrop Lite Spectrophotometer (ThermoScientific, Waltham, MA, U.S.A.). DNA sequencing of the PCR amplified ITS, Coxl, Nadh1, Hsp90, and $\beta$-Tub products employed oligonucleotides (V9G, ITS2, ITS3, LR1), (COXF4N, COXR4N), (NADHF1 and NADHRl), (HCF90_F1 and HSP90_Rl), (TUBUF2, TUBUR1, TUB2T22 [O'Donnell and Cigelnik 1997], TUB2REV 5'CAGCGGGGCGAAGCCGATC-3', TUB2FOR 5'-CCAGCTGAACT $\left.C G G A C C T G C G-3^{\prime}\right)$, respectively. All DNA sequencing was performed at the W. M. Keck Biotechnology Resource Laboratory, Yale School of Medicine, New Haven, CT, U.S.A. The resulting DNA sequences were deposited into GenBank with the following accession numbers: ITS [MK163944]; Coxl [MK164270]; Nadh1 [MK164269]; Hsp90 [MK164275]; $\beta-T u b$ [MK164274].

The aforementioned five genes/regions of DNA sequences were employed as a query for BLASTn analysis in databases at GenBank (https://blast.ncbi.nlm.nih.gov). The allied taxa and the corresponding DNA sequences of allied taxa for loci ITS, Cox1, Nadh1, $H s p 90, \beta-T u b$ were obtained from GenBank (Blair et al. 2008). Sixteen additional species of Phytophthora from Clade 7 and P. megasperma from Clade 6 with 26 isolates in total were selected for phylogenetic analyses (Jung et al. 2017b). Uncultured/unidentified samples, environmental samples, and samples with questionable identifications were excluded (Wheeler et al. 2003). The sequences of the unknown pathogen generated from the present study were deposited to GenBank; the accession numbers of the sequences and accession numbers of the taxa and isolates used in our phylogenetic analysis are presented in Table 1.

Alignment and phylogenetic analysis. Sequence data from ITS, Coxl, $\beta$-Tub, Nadhl, and Hsp 90 were aligned independently using MUSCLE (Edgar 2004), followed by manual correction, then were trimmed and concatenated with FABOX sequence alignment joiner (http://users-birc.au.dk/palle/php/fabox/alignment_joiner.php).

Phylogenetic analyses employed both maximum likelihood (ML) with MEGA X (Kumar et al. 2018; Tamura 1992) or Bayesian inference (BI) using MrBayes3.2.6 (Ronquist et al. 2012). The dataset had 26 concatenated nucleotide sequences of five genes/region with 4,250 positions, and all sites were treated with equal weight for the analysis. Gaps were treated as missing data. P. megasperma DDS3432 was designated as an outgroup. For ML analysis, a bootstrap was calculated with 1,000 replicates. For BI analysis, four Markov chains were used for one run from random starting trees for two million generations. Tree sampling frequency was 1,000 generations. The first one-tenth generations were discarded as burn-in. The majority rule consensus tree of all remaining trees was computed. Branches that received Bayesian posterior probabilities of at least 0.95 (BPP) were considered to be significantly supported. Phylogenetic trees were constructed using TreeGraph2 (Stöver and Müller 2010).

Koch's postulates test. Healthy bare-root 5-year-old A. fraseri transplants were obtained from a cooperating Christmas tree grower and potted into 2-gallon (7.6 liter) plastic nursery containers in composted hardwood chips in June 2018. They were maintained with twice-daily overhead irrigation of $80 \mathrm{ml}$ per pot from a domestic, chlorinated water source in a nursery area with coarse crushed stone surface at the CAES Valley Laboratory. Six trees were inoculated on 6 July 2018. An additional six trees were wounded but not inoculated and held as controls. To inoculate the trees, a $5 \times 5 \mathrm{~mm}$ flap of bark was opened with a sterile scalpel to the depth of the cambium, and Phytophthora mycelium and an agar piece containing oospores $(2 \times 2 \mathrm{~mm}$, grown on $10 \% \mathrm{~V} 8$ agar for 1 month) were inserted under the bark flap. The flap was then closed and sealed with Parafilm. Controls were treated in the same manner as the inoculated trees, except that no agar or Phytophthora mycelium were introduced. Trees were then placed in a growth chamber with $16: 8 \mathrm{~h}$ light/dark fluorescent lighting and temperature set to a constant $15^{\circ} \mathrm{C}$. Plants were maintained without additional watering by placing the pot into a plastic bag and securing the bag around the stem to prevent evaporation from the potting medium. A binder clip held the excess plastic from the top of the bag closed but did not clamp the stem of the tree.

After 17 days (23 July 2018), the first signs of wilting were visible with one of the six inoculated trees. Two additional inoculated trees were destructively examined at this date, and all three trees had interior lesions extending upward from the point of inoculation. Three control trees were examined and had healthy tissue surrounding the wounded site. The tree experiencing wilting of foliage was used to reisolate Phytophthora, using apple baiting with the methods described above. At 26 days postinoculation, the three remaining inoculated trees were examined for infection and two were used to reisolate $P h y$ tophthora using apples. The procedure was identical to the initial isolation from the field samples, except that two tissue samples each were taken from above and below the inoculation point along the 
margin of the lesion, with four samples (in total) from each tree being used to inoculate each apple.

Apples were incubated in the growth chamber for 2 weeks, whereupon the brown lesions had developed sufficiently for pieces to be removed with a sterile scalpel and cultured on $10 \%$ V8 agar.

Cultures of Phytophthora were allowed to grow on the 10\% V8 for 2 weeks to allow production of oospores for measurement and confirmation of identity.

\section{Results}

The results of phylogenetic analyses employing maximum likelihood or Bayesian inference using ITS, Coxl, $\beta$-Tub, Nadhl, and $H s p 90$ sequences were highly similar and led to the same conclusion. $P$. abietivora is a sister species to $P$. flexuosa, and is in the same subclade as P. europaea, while other Clade 7 Phytophthora species reside in different subclades (Fig. 1).

Taxonomy. Phytophthora abietivora D.W. Li, N.P. Schultes, J. A. LaMondia, R. S. Cowles sp. nov. MycoBank \# MB 830083. Oogonia, oospores and antheridia: Oogonia developed on V8. Oogonia were borne terminally or laterally and globose to subglobose, colorless to golden-yellow (Fig. 2a, b), infrequently with a tapering base, (32.1) 41.5-51.9 (55.5) × (30.6) 38.1-47.5 (50.5) $\mu \mathrm{m}$ (mean \pm SD: $46.7 \pm$ $5.2 \times 42.8 \pm 4.7 \mu \mathrm{m}, n=35)$. Oospores were plerotic to slightly aplerotic, globose and often contained 1-3 ooplasts, colorless to brownish yellow (Fig. 2a, b), (26.5) 33.7-41.3 (42.5) $\mu \mathrm{m}$ (mean \pm SD: $37.5 \pm$ $3.8 \mu \mathrm{m}, n=35)$, thick walled (3.5) 4.4-6.4 (7.1) $\mu \mathrm{m}(5.4 \pm 1 \mu \mathrm{m}$, $n=35$ ), colorless to pale brownish yellow, smooth to verruculose. Antheridia were formed terminally or laterally, were subglobose, ovoid to irregular shaped and mostly paragynous (Fig. 2b) or occasionally amphigynous unicellular (Fig. 2b), (8.6) 10.5-15.5 (18.2) $\times(7.6)$ 8.2-13.2 (17.4) $\mu \mathrm{m}$ (mean \pm SD: $13 \pm 2.5 \times 10.7 \pm 2.5 \mu \mathrm{m}, n=23$ ).

Sporangia, hyphal swellings, and chlamydospores. Sporangia of P. abietivora were not observed on solid PDA agar and V8 flooded with soil extract and/or imbedded with root pieces on $20^{\circ} \mathrm{C}$ and room temperature but developed on $10 \% \mathrm{~V} 8$ plates flooded with root extract at $15^{\circ} \mathrm{C}$ and held under fluorescent lighting for 1 week. Sporangia were developed terminally on unbranched sporangiophores solitarily or in a cluster with two to three sporangia, ovoid or ellipsoid, hyaline or pale yellow, noncaducous and nonpapillate, flat or rounded at the apex with a lenticular plug (Fig. 2c, d). Sporangia were (27.1) $29.8 \pm 37.2(41.8) \times(17.7) 22.2 \pm 28.0(30.8) \mu \mathrm{m}$ (mean \pm SD: $33.5 \pm 3.7 \times 25.1 \pm 2.9 \mu \mathrm{m}, n=30)$. The length/breadth ratio of the sporangia averaged $1.34 \pm 0.13$. Occasionally a nesting sporangium developed through the empty preceding one (Fig. 2e). Zoospores were (10.6) 12.5-15.1 (16.7) $\times$ (9.8) 10.2-12.2 (13) $\mu \mathrm{m}$ (mean \pm SD: $13.8 \pm 1.3 \times 11.2 \pm 1 \mu \mathrm{m}, n=30)$, discharged through a wide exit pore (6-7.5 $\mu \mathrm{m}$ wide). They were primarily pyriform, also oval, globose to reniform, motile, becoming globose on encystment. (Fig. $2 \mathrm{f}, \mathrm{g})$. Chlamydospores were present, globose or subglobose, colorless to pale yellow, smooth, 7-11.5 $\mu \mathrm{m}$ (Fig. 2h). In solid agar flooded with soil extract, irregular coralloid hyphal swellings were formed (Fig. 2i).

Holotype. U.S.A., Connecticut, Brooklyn, Allen Hill Farm $\left(41^{\circ} 45.997^{\prime} \mathrm{N} 71^{\circ} 55.182^{\prime} \mathrm{W}\right)$, from infected root of a Christmas tree of Abies fraseri (Pursh) Poir., 10 October 2017, R.S. Cowles, UAMH 12075 (RC2017-1). Holotype specimen is a living specimen being maintained via lyophilization at UAMH Centre for Global Microfungal Biodiversity, The Gage Research Institute, Toronto, Canada. Extype is NRRL66892.

Etymology. Latin, abies, referring to conifer genus Abies and -vora, ones that eat.

Comments. P. abietivora develops rather large oospores with very thick walls ( $37.5 \pm 3.8 \mu \mathrm{m}$ in size, $5.4 \pm 1 \mu \mathrm{m}$ in thickness), which differentiate it from morphologically and phylogenetically related species, $P$. flexuosa $(32.2 \pm 2.7 \mu \mathrm{m}$ in size, $3.1 \pm 0.5 \mu \mathrm{m}$ in thickness), and $P$. europaea $(33.2 \pm 5.3 \mu \mathrm{m}$ in size, $2.5 \pm 0.7 \mu \mathrm{m}$ in

Table 1. Taxa, isolates, their sequences, and GenBank accession numbers used in the phylogenetic analysis ${ }^{\mathrm{a}}$

\begin{tabular}{|c|c|c|c|c|c|c|c|c|c|c|c|}
\hline \multirow[b]{2}{*}{ Clade } & \multirow[b]{2}{*}{ Taxa } & \multirow[b]{2}{*}{ Type } & \multirow[b]{2}{*}{ Culture no. } & \multirow[b]{2}{*}{ Host } & \multirow[b]{2}{*}{ Location } & \multicolumn{5}{|c|}{ GenBank accession numbers } & \multirow[b]{2}{*}{ Reference } \\
\hline & & & & & & ITS & Cox1 & $\beta$-Tub & NADH1 & HSP90 & \\
\hline Clade 7a & $\begin{array}{l}\text { Phytophthora } \\
\text { abietivora }\end{array}$ & holo-type & UAMH 12075 & $\begin{array}{l}\text { Christmas tree of } \\
\text { Abies fraseri }\end{array}$ & U.S.A. & MK163944 & MK164270 & MK164274 & MK164269 & MK164275 & This study \\
\hline Clade 7a & P. attenuata & ex-type & CBS 141199 & Castanopsis carlesii & Taiwan & KU517154 & KU517148 & KU899277 & KU899519 & KU899434 & Jung et al. 2017a \\
\hline Clade 7b & P. cinnamomi & ex-type & CBS 144.22 & $\begin{array}{l}\text { Cinnaтотит } \\
\text { burmannii }\end{array}$ & Indonesia & KU899160 & KU899315 & KU899233 & KU899475 & KU899390 & Scanu et al. 2014 \\
\hline Clade 7a & P. europaea & ex-type & CBS 109049 & Quercus robur & France & HQ261556 & KU681022 & EU079482 & KU899469 & EU079485 & Jung et al. 2002 \\
\hline Clade $7 \mathrm{a}$ & P. europaea & & CBS 109051 & Quercus sp. & France & KU899157 & KU899312 & KU899229 & KU899470 & KU899384 & Jung et al. 2002 \\
\hline Clade 7a & P. flexиosa & & CBS 141202 & Fagus hayatae & Taiwan & KU899193 & KU899348 & KU899271 & KU899513 & KU899428 & Jung et al. 2017b \\
\hline Clade 7a & P. flexuosa & & TW79 & Fagus hayatae & Taiwan & KU899220 & KU899375 & KU899303 & KU899545 & KU899460 & Jung et al. 2017b \\
\hline Clade 7a & P. flexuosa & ex-type & CBS 141201 & Fagus hayatae & Taiwan & KU517152 & KU517146 & KU899302 & KU899544 & KU899459 & Jung et al. 2017a \\
\hline Clade $7 \mathrm{a}$ & P. formosa & & CBS 141204 TW14 & Q. glandulifera & Taiwan & KU899201 & KU899356 & KU899280 & KU899522 & KU899437 & Jung et al. 2017a \\
\hline Clade 7a & P. formosa & ex-type & CBS 141203 & $\begin{array}{l}\text { Araucaria } \\
\text { cunninghamii }\end{array}$ & Taiwan & KU517153 & KU517147 & KU899270 & KU899512 & KU899427 & Jung et al. 2017a \\
\hline Clade 7a & P. formosa & & TW13 & Quercus glandulifera & Taiwan & KU899199 & KU899354 & KU899278 & KU899520 & KU899435 & Jung et al. $2017 \mathrm{~b}$ \\
\hline Clade 7a & P. fragariae & & ATCC 36057 & Fragaria xananassa & U.K. & HQ261564 & KU681021 & EU079744 & KU899548 & EU079747 & \\
\hline Clade 7a & P. fragariae & ex-type & CBS 209.46 & Fragaria & U.K. & HQ643230 & - & - & - & - & $\begin{array}{l}\text { C. J. Hickman, } \\
\text { unpublished }\end{array}$ \\
\hline Clade 7a & P. intricata & ex-type & CBS 141211 & Quercus tarokoensis & Taiwan & KU517155 & KU517149 & KU899284 & KU899526 & KU899441 & Jung et al. 2017a \\
\hline Clade 6 & P. megasperma & & DDS3432 & Soil Banksia sp. & Australia & HQ012949 & HQ012867 & JN547608 & KM883175 & HQ012906 & Jung et al. 2011 \\
\hline Clade 7b & P. niederhauserii & & CBS 124086 & $\begin{array}{l}\text { Chamaecyparis } \\
\text { lawsoniana }\end{array}$ & Hungary & GU230789 & GU477617 & GU477613 & GU477619 & KU899389 & Józsa et al. 2010 \\
\hline Clade 7a & P. rubi & ex-type & CBS 967.95 & Rubus idaeus & U.K. & AF139370 & DQ674736 & KU899234 & KU899476 & KU899391 & $\begin{array}{l}\text { Man In't Veld } \\
2007\end{array}$ \\
\hline Clade 7a & P. uliginosa & ex-type & CBS 109054 & Quercu robur & Poland & AF449495 & KU681023 & EU080012 & KU899471 & EU080014 & Jung et al. 2002 \\
\hline Clade 7a & P. uliginosa & & CBS 109055 & Quercus petraea & Germany & HQ261722 & - & EU079693 & - & EU079696 & Jung et al. 2002 \\
\hline Clade 7a & P. uniformis & ex-type & IMI 392315 & Alnus glutinosa & Sweden & GU259293 & - & - & - & - & $\begin{array}{l}\text { Brasier et al. } \\
2004\end{array}$ \\
\hline Clade 7a & P. uniformis & & WPC P10565 & Alnus glutinosa & Hungary & KU899221 & KU899376 & KU899304 & KU899546 & KU899461 & Ioos et al. 2006 \\
\hline Clade 7a & $P . \mathrm{x}$ aln $i$ & ex-type & IMI 392314 & Alnus glutinosa & U.K. & KU681013 & KU681017 & KU899238 & KU899480 & KU899395 & $\begin{array}{l}\text { Brasier et al. } \\
2004\end{array}$ \\
\hline Clade 7a & P. $\mathrm{x}$ cambivora (A2) & neo-type & CBS 141218 & Quercus pubescens & Italy & KU899179 & KU899334 & KU899255 & KU899497 & KU899412 & Jung et al. 2017b \\
\hline Clade 7a & P. x heterohybrida (A2) & ex-type & CBS 141207 & $\begin{array}{l}\text { Baiting; tributary of } \\
\text { Ha-pen River }\end{array}$ & Taiwan & KU517151 & KU517145 & KU899290 & KU899532 & KU899447 & Jung et al. 2017a \\
\hline Clade 7a & P. x incrassata (A2) & ex-type & CBS 141209 & $\begin{array}{l}\text { Baiting; tributary of } \\
\text { Ha-pen River }\end{array}$ & Taiwan & KU517156 & KU517150 & KU899286 & KU899528 & KU899443 & Jung et al. 2017a \\
\hline Clade 7a & P. $\mathrm{x}$ multiformis & ex-type & $\begin{array}{l}\text { IMI 392316, WPC } \\
\text { P16202, PD_01913 }\end{array}$ & Alnus glutinosa & Netherlands & AF139368 & KU681018 & KU899239 & KU899481 & KU899396 & $\begin{array}{l}\text { Brasier et al. } \\
2004\end{array}$ \\
\hline
\end{tabular}

a Abbreviations of isolates and culture collections: ATCC = American Type Culture Collection, Manassas, U.S.A.; CBS = The Westerdijk Fungal Biodiversity Institute (formerly Centraalbureau voor Schimmel cultures), Utrecht, the Netherlands; IMI = CABI Bioscience, U.K.; PD = Phytophthora Database (http:// www.phytophthoradb.org); WPC = World Phytophthora Collection, University of California Riverside, U.S.A.; other isolate names and numbers are as given by the collectors and on GenBank, respectively. 
thickness) (Jung et al. 2002, 2017b). P. uliginosa is another species sharing some similarities in morphology, but its oospores are bigger with thinner walls $(41.3 \pm 6.1 \mu \mathrm{m}$ in size, $4.2 \pm 0.7 \mu \mathrm{m}$ in thickness $)$ (Jung et al. 2017b). The sporangia of $P$. uliginosa $(67.0 \pm 8.5 \times 42.4 \pm$ $6.4 \mu \mathrm{m})$ are much bigger than those of $P$. abietivora $(33.5 \pm 3.7 \times$ $25.1 \pm 2.9 \mu \mathrm{m}$ ) (Jung et al. 2017b). The size of zoospores of $P$. abietivora $(13.8 \pm 1.3 \times 11.2 \pm 1 \mu \mathrm{m})$ are similar to those of $P$. flexuosa
$(13.3 \pm 1.3 \mu \mathrm{m})$, smaller than those of $P$. europaea $(15.3 \pm 2.0 \mu \mathrm{m})$, but larger than those of $P$. uliginosa $(11.9 \pm 1 \mu \mathrm{m}$ ) (Jung et al. 2017b). All four of these species develop hyphal swellings.

$P$. abietivora and $P$. uliginosa share high similarities in ITS sequences. However, $P$. abietivora and $P$. uliginosa are in different phylogenetic clades in the phylogenetic analysis using five loci (Fig. 1).

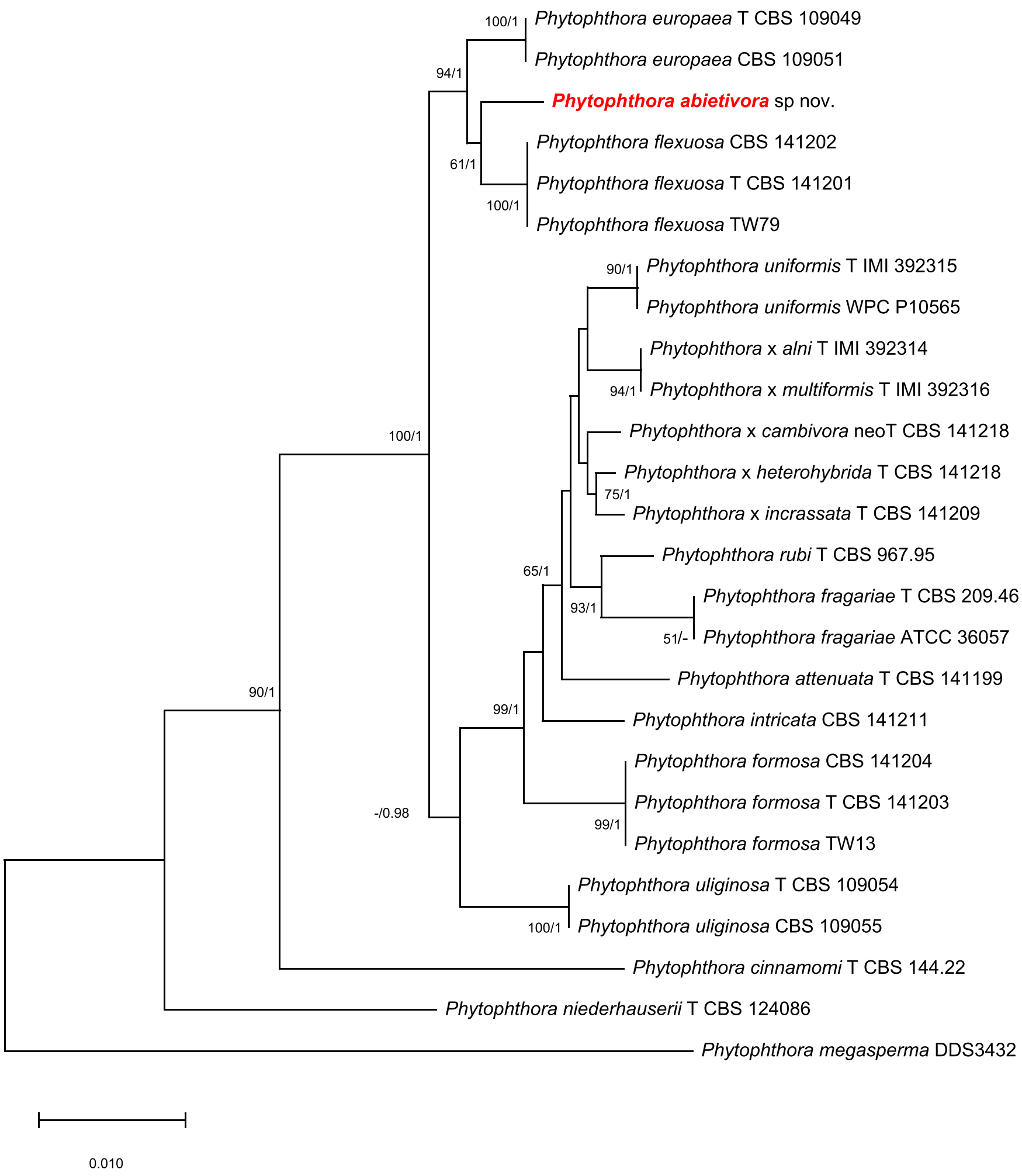

Fig. 1. Maximum likelihood analysis of Phytophthora abietivora (ex-type) and allied taxa based on concatenated ITS, Cox1, $\beta$-Tub, Nadh1, and Hsp90 sequence data. Phytophthora megasperma DDS3432 is included as outgroup. The bootstrap test was conducted with 1,000 replicates. Bootstrap values $>50 \%$ (before the slash) and Bayesian posterior probabilities $(>0.90)$ (after the slash) were indicated at the nodes. The scale bar indicates the number of expected changes per site. $T$ indicates the extypes used in the analysis. 
Symptoms in the field. All 60 Fraser firs planted in 2010 were dead by 2013 due to root rot infection, while very few mortalities occurred among the remaining 840 Christmas trees of other species planted in the same year. Following replanting in 2015, each succeeding year had trees with symptoms of the foliage turning reddish brown and current-year shoots bending downward. When the root crowns were cut open, the cambium and cortical layer had turned red (Fig. 3A, B).

Koch's postulates test. All inoculated trees became diseased. Symptoms included wilting of terminals (two of six inoculated trees) and necrotic tissue in the root crown and stem portions of the plants (all six inoculated trees) (Fig. 3). Chlorosis of the current season's needles was too subtle to quantify. Phytophthora was recovered from all three trees from which reisolation was attempted. None of the reisolation attempts from samples taken from the upper margin of the lesion, on the stem of the tree, were successful. However, reisolations were successful for five of six samples taken from the lower margin of the lesions. There was no disease in any of the control trees.
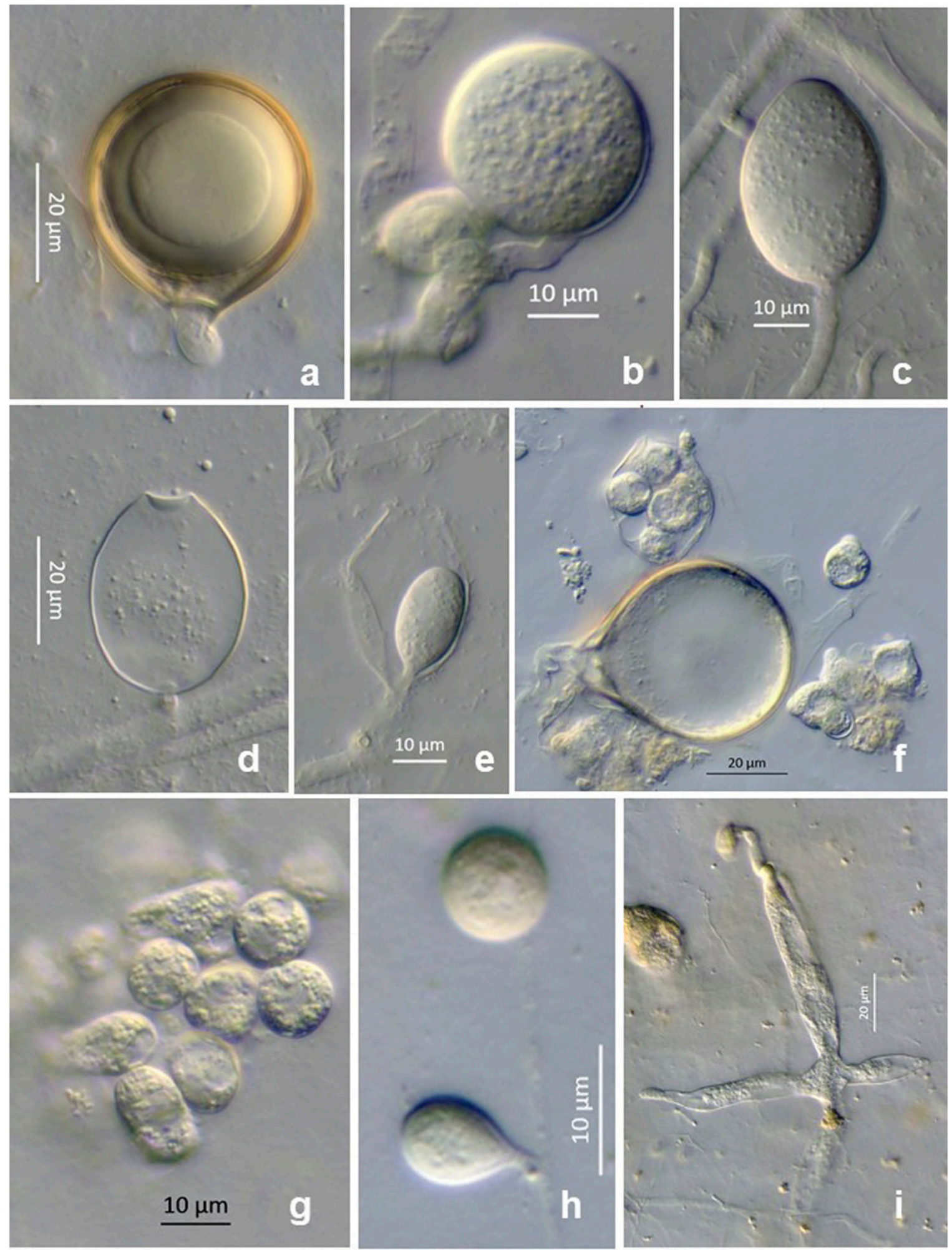

Fig. 2. Phytophthora abietivora (Holotype UAMH 12075). a, Oogonium and oospore. b, Immature oogonium and antherium. c, Sporangium. d, Empty sporangium. e, Nesting sporangium. f, Zoospores, sporangium, and oogonium. g, Zoospores. h, Chlamydospores. i, Irregular coralloid hyphal swellings. 
Microscopic examination of the culture determined that the oospores had the same dimensions and morphological characters as the original isolate.

\section{Discussion}

It has been estimated that there are 100 to 500 species of Phytophthora unknown to science (Brasier 2009). Jung et al. (2018) indicated that a potentially high number of undescribed Phytophthora species may exist and the unknown origin of many known aggressive Phytophthora species are a huge threat to the health and sustainability of forests, ecosystems, managed forests, and crop production systems worldwide. The discovery of a new species, P. abietivora, in Connecticut suggests that it might be the same scenario in the U.S.A. Nine species of Phytophthora have been reported from Connecticut

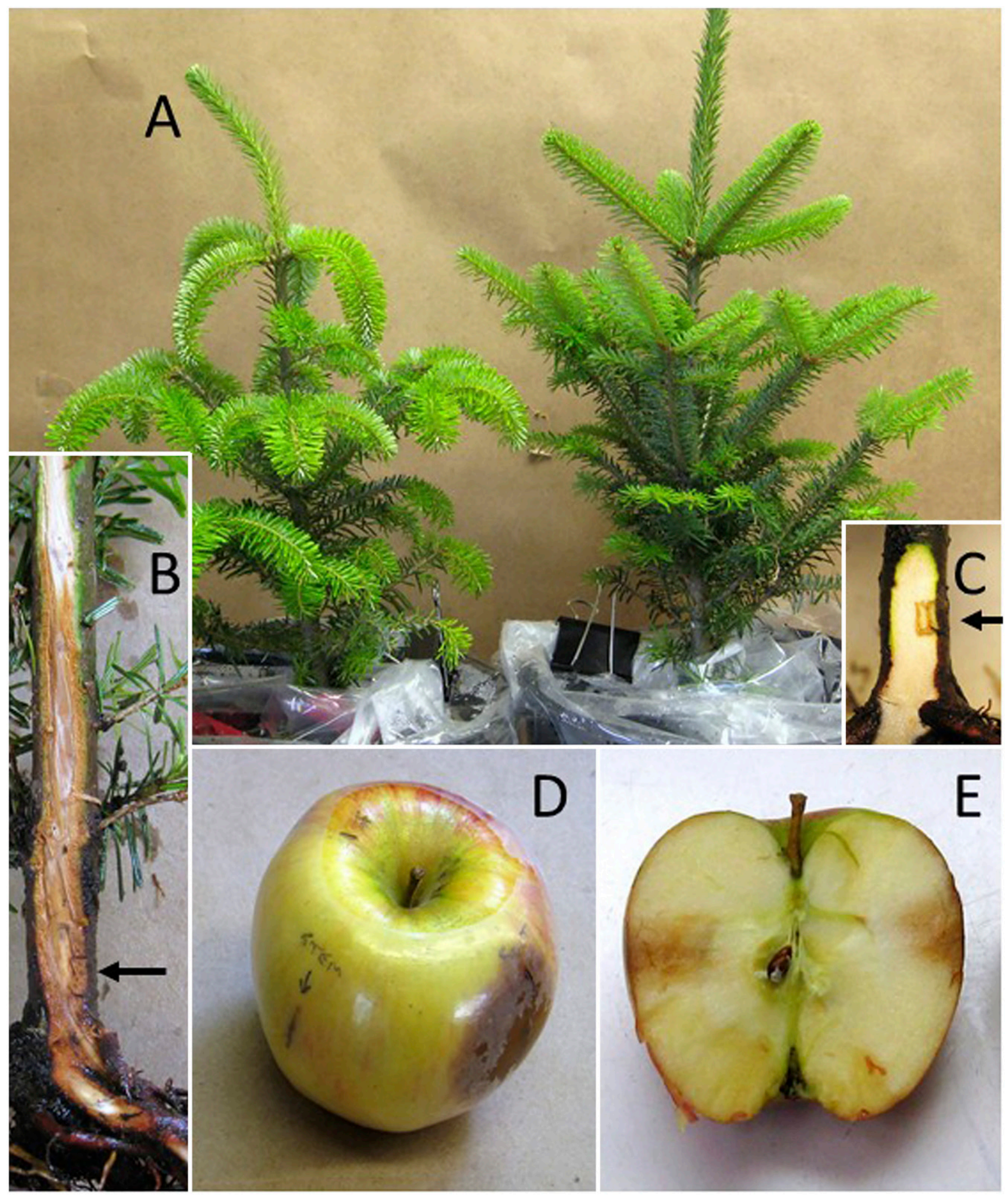

Fig. 3. Representative potted Abies fraseri and inoculated apples used to test Koch's Postulates. A, Inoculated (left) and uninoculated control (right) fir trees at 17 days post inoculation. The location of the bark flaps, marked with arrows, shows interior discoloration in lesions extending from the inoculation site in (B), but not in the stem of the uninoculated control tree (C). Brown discoloration of the flesh of an apple (D) developed about 2 weeks after inoculation with infected tissue taken from the roots (right side) but not when taken from the upper margin of the lesion on the stem (left side). The bisected apple (E) shows brown discoloration developing from inoculation slits made on opposite sides of the same apple, both originating from infected root tissue. 
to date (Farr et al. 2019). It is likely that the number of Phytophthora spp. in Connecticut is significantly underestimated.

The results of our phylogenetic analysis were in agreement with an analogous study by Jung et al. (2017b), which showed $P$. europaea and $P$. uliginosa to be affiliated with the same subclade in Clade $7 \mathrm{a}$, yet distinct and separate from other subclades. The new species, $P$. abietivora, shared the same subclade with $P$. europaea and $P$. uliginosa, but segregated distinctly from these two species (Fig. 1). Both morphological studies and phylogenetic analyses using the sequences of five loci support the same conclusion that $P$. abietivora constitutes a distinct species.

Phylogenetic analyses using each individual locus were conducted prior to multilocus analysis. ITS alone cannot differentiate $P$. abietivora from $P$. flexuosa and two other closely related species. Cox 1 and $N a d h 1$ cannot either, due to low significance levels. $\beta$-Tub and $H s p 90$ seem to be able to differentiate them, but they are less reliable than multiple loci for identification purposes. Overall, our analyses of P. abietivora sequences confirms findings by Blair et al. (2008) that multilocus analysis is crucial to achieve adequate, species-level phylogenetic resolution within Phytophthora.

Our results also showed that $P$. abietivora is a pathogen causing root rot disease of Fraser fir Christmas trees. Observation in the field indicated that $P$. abietivora caused a significant loss in the Fraser fir Christmas tree farm where the pathogen was discovered. However, its host range remains unknown. Zoospores and sporangia of $P$. abietivora were not readily observed and multiple attempts described herein were required. Not all species or isolates of the same species develop sporangia on sterile media under laboratory conditions (Werres et al. 2001) and therefore, zoospores are not always observed. Limited production of zoospores may make species similar to $P$. abietivora difficult to detect through standard environmental surveys for Phytophthora spp. by using baits in streams (e.g., Klotz et al. 1959), and as such, they may be underrepresented. Sporangia may germinate directly to develop secondary sporangia (Domsch et al. 1980) or hyphae to infect hosts. Formation of sporangia of some species need to be induced with nonsterile soil extract, specific bacteria, or flooding with water (Domsch et al. 1980; Werres et al. 2001; Zentmyer and Erwin 1970). P. cinnamomi failed to develop sporangia in soil extract treated at $40-50^{\circ} \mathrm{C}$ for $10 \mathrm{~min}$ or in soils steamed at $60^{\circ} \mathrm{C}$ for $30 \mathrm{~min}$ (Broadbent and Baker 1974). Under sterile conditions, sporangia of $P$. cinnamomi only developed by a thorough washing with a salt solution (Zentmyer and Erwin 1970). Sporangia production of $P$. fragariae was induced by nonsterile pond water (Hickman and Goode 1953). In our study, colonies flooded with nonsterile soil extract with or without root pieces or flooded with distilled water developed hyphal swellings but no zoospores; $P$. abietivora only developed sporangia and zoospores on agar plates containing $10 \% \mathrm{~V} 8$ that were flooded with root extract solution at $15^{\circ} \mathrm{C}$. A number of species of Phytophthora develop hyphal swellings, such as $P$. cinnamomi and P. plurivora (Domsch et al. 1980; Jung and Burgess 2009). The function of hyphal swellings remains to be studied.

\section{Acknowledgments}

The authors are grateful to Dr. Carole Cheah for accessing some literature, Michelle Salvas for technical assistance, and Charles Langevin, Allen Hill Farm, Brooklyn, CT, for allowing us to collect the specimens and soil samples and conduct field experiments for the study on his farm.

\section{Literature Cited}

Adams, G. C., Jr. 1988. First report of Phytophthora cactorum and P. citricola causing crown rot of fir species in Michigan. Plant Dis. 72:79.

Blair, J. E., Coffey, M. D., Park, S.-Y., Geiser, D. M., and Kang, S. 2008. A multilocus phylogeny for Phytophthora utilizing markers derived from complete genome sequences. Fungal Genet. Biol. 45:266-277.

Brasier, C. 2009. Phytophthora biodiversity: how many Phytophthora species are there? Pages 101-115 in: Phytophthoras in Forests and Natural Ecosystems: Proceedings of the Fourth Meeting of the International Union of Forest Research Organizations (IUFRO) Working Party S07.02.09. E. M. Goheen and S. J. Frankel, eds. United States Department of Agriculture, Forest Service, Monterey, CA.

Brasier, C. M., Delcan, J., Cooke, D. E., Jung, T., and Man In't Veld, W. A. 2004. Phytophthora alni sp. nov. and its variants: designation of emerging heteroploid hybrid pathogens spreading on Alnus trees. Mycol. Res. 108:1172-1184.
Broadbent, P., and Baker, K. 1974. Association of bacteria with sporangium formation and breakdown of sporangia in Phytophthora spp. Aust. J. Agric. Res. 25:139-145.

Chastagner, G. A., and Benson, D. M. 2000. The Christmas tree: Traditions, production, and diseases. Plant Health Prog. doi:10.1094/PHP-2000-1013-01-RV

Domsch, K. H., Gams, W., and Anderson, T.-H. 1980. Compendium of Soil Fungi. IHW-Verlag, Eching, Germany.

Edgar, R. C. 2004. MUSCLE: multiple sequence alignment with high accuracy and high throughput. Nucleic Acids Res. 32:1792-1797.

Erwin, D. C., and Ribeiro, O. K. 1996. Phytophthora diseases worldwide American Phytopathological Society. APS Press, St. Paul, Minnesota.

Farr, D., Rossman, A., Palm, M., and McCray, E. 2019. Fungal databases, systematic mycology and microbiology laboratory. ARS-USDA. https:// nt.ars-grin.gov/fungaldatabases

Ferguson, A., and Jeffers, S. 1999. Detecting multiple species of Phytophthora in container mixes from ornamental crop nurseries. Plant Dis. 83:1129-1136.

Grand, L. 1985. North Carolina plant disease index. North Carolina Agric. Res. Serv. Tech. Bull. 240:1-157.

Hickman, C. J., and Goode, P. M. 1953. A new method of testing the pathogenicity of Phytophthora fragariae. Nature 172:211-212.

Hinesley, L. E., Parker, K., and Benson, D. 2000. Evaluation of seedlings of Fraser, momi, and Siberian fir for resistance to Phytophthora cinnamomi. HortScience $35: 87-88$

Hoover, B. K., and Bates, R. M. 2013. Susceptibility of Fraser, Canaan, and Nordmann fir to root rot incited by Phytophthora cactorum and Phytophthora drechsleri. HortTechnology 23:44-50.

Huang, H., Jeffers, S., Layne, D., and Schnabel, G. 2004. AFLP analysis of Phytophthora cactorum isolates from strawberry and other hosts: implications for identifying the primary source of inoculum. Plant Dis. 88:714-720.

Hunt, R. S. 1993. Abies. Flora of North America North of Mexico. Flora of North America Editorial Committee, eds. Oxford University Press, Oxford, UK.

Ioos, R., Andrieux, A., Marçais, B., and Frey, P. 2006. Genetic characterization of the natural hybrid species Phytophthora alni as inferred from nuclear and mitochondrial DNA analyses. Fungal Genet. Biol. 43:511-529.

Jeffers, S., and Aldwinckle, H. 1987. Enhancing detection of Phytophthora catorum in naturally infested soil. Phytopathology 77:1475-1482.

Józsa, A., Bakonyi, J., Belbahri, L., Nagy, Z., Szigethy, A., Bohár, G., and Woodward, S. 2010. A new species of Phytophthora reported to cause root and collar rot of common boxwood, Nordmann fir and Port Orford cedar in Hungary. Plant Pathol. 59:1166-1167.

Judelson, H. S., and Blanco, F. A. 2005. The spores of Phytophthora: weapons of the plant destroyer. Nat. Rev. Microbiol. 3:47-58.

Jung, T., and Burgess, T. 2009. Re-evaluation of Phytophthora citricola isolates from multiple woody hosts in Europe and North America reveals a new species, Phytophthora plurivora sp. nov. Persoonia 22:95-110.

Jung, T., Chang, T., Bakonyi, J., Seress, D., Pérez-Sierra, A., Yang, X., Hong, C. Scanu, B., Fu, C., and Hsueh, K. 2017a. Diversity of Phytophthora species in natural ecosystems of Taiwan and association with disease symptoms. Plant Pathol. 66:194-211.

Jung, T., Hansen, E. M., Winton, L., Osswald, W., and Delatour, C. 2002. Three new species of Phytophthora from European oak forests. Mycol. Res. 106: 397-411.

Jung, T., Jung, M. H., Scanu, B., Seress, D., Kovács, G. M., Maia, C., Pérez-Sierra A., Chang, T.-T., Chandelier, A., and Heungens, K. 2017b. Six new Phytophthora species from ITS Clade 7a including two sexually functional heterothallic hybrid species detected in natural ecosystems in Taiwan. Persoonia. Mol. Phylogeny Evol. Fungi 38:100-135.

Jung, T., Orlikowski, L., Henricot, B., Abad-Campos, P., Aday, A. G., Aguín Casal, O., Bakonyi, J., Cacciola, S. O., Cech, T., Chavarriaga, D., Corcobado, T., Cravador, A., Decourcelle, T., Denton, G., Diamandis, S., Doğmuş-Lehtijärvi, H. T., Franceschini, A., Ginetti, B., Green, S., Glavendekić, M., Hantula, J., Hartmann, G., Herrero, M., Ivic, D., Horta Jung, M., Lilja, A., Keca, N., Kramarets, V., Lyubenova, A., Machado, H., Magnano di San Lio, G., Mansilla Vázquez, P. J., Marçais, B., Matsiakh, I., Milenkovic, I., Moricca, S., Nagy, Z. Á., Nechwatal, J., Olsson, C., Oszako, T., Pane, A., Paplomatas, E. J., Pintos Varela, C., Prospero, S., Rial Martínez, C., Rigling, D., Robin, C., Rytkönen, A., Sánchez, M. E., Sanz Ros, A. V., Scanu, B., Schlenzig, A., Schumacher, J., Slavov, S., Solla, A., Sousa, E., Stenlid, J., Talgø, V., Tomic, Z., Tsopelas, P., Vannini, A., Vettraino, A. M., Wenneker, M., Woodward, S., Peréz-Sierra, A., and Deprez-Loustau, M. L. 2016. Widespread Phytophthora infestations in European nurseries put forest, semi-natural and horticultural ecosystems at high risk of Phytophthora diseases. For. Pathol. 46:134-163.

Jung, T., Pérez-Sierra, A., Durán, A., Jung, M. H., Balci, Y., and Scanu, B. 2018. Canker and decline diseases caused by soil-and airborne Phytophthora species in forests and woodlands. Persoonia 40:182-220.

Jung, T., Stukely, M., Hardy, G. S. J., White, D., Paap, T., Dunstan, W., and Burgess, T. 2011. Multiple new Phytophthora species from ITS Clade 6 associated with natural ecosystems in Australia: evolutionary and ecological implications. Persoonia 26:13-39.

Klotz, L., Wong, P.-P., and DeWolfe, T. 1959. Survey of irrigation water for the presence of Phytophthora spp. pathogenic to citrus. Plant Dis. Rep. 43:830-832. 
Kroon, L., Bakker, F., Van Den Bosch, G., Bonants, P., and Flier, W. 2004. Phylogenetic analysis of Phytophthora species based on mitochondrial and nuclear DNA sequences. Fungal Genet. Biol. 41:766-782.

Kuhlman, E. G., and Hendrix, F. 1963. Phytophthora root rot of Fraser Fir. Plant Dis. Rep. 47:552-553.

Kumar, S., Stecher, G., Li, M., Knyaz, C., and Tamura, K. 2018. MEGA X: Molecular evolutionary genetics analysis across computing platforms. Mol. Biol. Evol. 35:1547-1549.

Man in 't Veld, W. A. 2007. Gene flow analysis demonstrates that Phytophthora fragariae var. rubi constitutes a distinct species, Phytophthora rubi comb. nov. Mycologia 99:222-226.

Martin, F. N., Blair, J. E., and Coffey, M. D. 2014. A combined mitochondrial and nuclear multilocus phylogeny of the genus Phytophthora. Fungal Genet. Biol. 66:19-32.

McKeever, K., and Chastagner, G. 2016. A survey of Phytophthora spp. associated with Abies in US Christmas tree farms. Plant Dis. 100:1161-1169.

O'Donnell, K., and Cigelnik, E. 1997. Two divergent intragenomic rDNA ITS2 types within a monophyletic lineage of the fungus Fusarium are nonorthologous. Mol. Phylogenet. Evol. 7:103-116.

Pettersson, M., Frampton, J., Rönnberg, J., Shew, H., Benson, D., Kohlway, W., Escanferla, M., and Cubeta, M. 2017. Increased diversity of Phytophthora species in Fraser fir Christmas tree plantations in the Southern Appalachians. Scand. J. For. Res. 32:412-420.

Phytophthora Database. 2018. Phytophthora Database. http://www.phytophthoradb. org/

Quesada-Ocampo, L., Fulbright, D., and Hausbeck, M. 2009. Susceptibility of Fraser fir to Phytophthora capsici. Plant Dis. 93:135-141.

Ronquist, F., Teslenko, M., van der Mark, P., Ayres, D. L., Darling, A., Höhna, S., Larget, B., Liu, L., Suchard, M. A., and Huelsenbeck, J. P. 2012. MrBayes 3.2: efficient Bayesian phylogenetic inference and model choice across a large model space. Syst. Biol. 61:539-542.

Scanu, B., Hunter, G. C., Linaldeddu, B. T., Franceschini, A., Maddau, L., Jung, T., and Denman, S. 2014. A taxonomic re-evaluation reveals that Phytophthora cinnamomi and P. cinnamomi var. parvispora are separate species. For. Pathol. 44:1-20.

Shamoun, S., Rioux, D., Callan, B., James, D., Hamelin, R., Bilodeau, G., Elliott, M., Levesque, C. A., Becker, E., McKenney, D., Pedlar, J., Bailey, K., Briere, S., Niquidet, K., and Allen, E. 2018. An overview of Canadian research activities on diseases caused by Phytophthora ramorum: Results, progress and challenges. Plant Dis. 102:1218-1233.

Shew, H., and Benson, D. 1981. Fraser fir root rot induced by Phytophthora citricola. Plant Dis. 65:688-689.

Stöver, B. C., and Müller, K. F. 2010. TreeGraph 2: combining and visualizing evidence from different phylogenetic analyses. BMC Bioinformatics 11:7.

Talgø, V., and Chastagner, G. 2012. Phytophthora on Abies spp. (true firs). JKI Data Sheets-Plant Diseases and Diagnosis:1-14.

Tamura, K. 1992. Estimation of the number of nucleotide substitutions when there are strong transition-transversion and $\mathrm{G}+\mathrm{C}$-content biases. Mol. Biol. Evol. 9: 678-687.

Tsao, P. 1990. Why many phytophthora root rots and crown rots of tree and horticultural crops remain undetected. EPPO Bull. 20:11-17.

Tucker, C. M. 1931. Taxonomy of the genus Phytophthora de Bary. Univ. Mo. Agric. Experiment Stn. Res. Bull. 153:1-208.

Van den Ende, A., and De Hoog, G. 1999. Variability and molecular diagnostics of the neurotropic species Cladophialophora bantiana. Stud. Mycol. 43:151-162.

Vilgalys, R., and Hester, M. 1990. Rapid genetic identification and mapping of enzymatically amplified ribosomal DNA from several Cryptococcus species. J. Bacteriol. 172:4238-4246.

Werres, S., Marwitz, R., In't Veld, W. A. M., De Cock, A. W., Bonants, P. J., De Weerdt, M., Themann, K., Ilieva, E., and Baayen, R. P. 2001. Phytophthora ramorum sp. nov., a new pathogen on Rhododendron and Viburnum. Mycol. Res. 105:1155-1165.

Wheeler, D. L., Church, D. M., Federhen, S., Lash, A. E., Madden, T. L., Pontius, J. U., Schuler, G. D., Schriml, L. M., Sequeira, E., Tatusova, T. A., and Wagner, L. 2003. Database resources of the National Center for Biotechnology. Nucleic Acids Res. 31:28-33.

White, T. J., Bruns, T., Lee, S., and Taylor, J. 1990. Amplification and direct sequencing of fungal ribosomal RNA genes for phylogenetics. Pages 315-322 in: PCR protocols: a guide to methods and applications. M. A. Innis, D. H. Gelfand, J. J. Sninsky, and T. J. White, eds. Vol. 18. Academic Press, Inc., New York.

Williams, R. L., and Haynes, S. C. 1982. Index of plant diseases in West Virginia Plant Pest Control Division, West Virginia Department of Agriculture.

Zentmyer, G., and Erwin, D. 1970. Development and reproduction of Phytophthora. Phytopathology 60:1120-1127. 